\title{
Killer Cell Immunoglobulin-Like Receptor 3DL1
}

National Cancer Institute

\section{Source}

National Cancer Institute. Killer Cell Immunoglobulin-Like Receptor 3DL1. NCI Thesaurus. Code C104361.

Killer cell immunog lobulin-like receptor 3DL1 (444 aa, $\sim 49 \mathrm{kDa}$ ) is encoded by the human KIR3DL1 gene. This protein plays a role in the modulation of cell-mediated cytotoxicity. 